\title{
KESALAHAN BERBAHASA TATARAN MORFOLOGI DALAM PENULISAN TAKRIR MEDIA SOSIAL GUBERNUR DI INDONESIA
}

\author{
Metah Aprilia Ardian ${ }^{1}$, Wildan Ghufron ${ }^{2}$, Sawitri $^{3}$ \\ Universitas Ahmad Dahlan \\ metah1700003149@webmail.uad.ac.id ${ }^{1}$ \\ wildan1715003127@webmail.uad.ac.id ${ }^{2}$ \\ fitriasawitri831@gmail.com ${ }^{3}$
}

\begin{abstract}
ABSTRAK
Penelitian ini bertujuan untuk mendapatkan data dan informasi tentang kesalahan berbahasa gubernur di Indonesia dalam bidang morfologi. Metode penelitian yaitu menggunakan metode kualitatif. Teknik pengumpulan data menggunakan teknik simak catat. Teknik analisis data menggunakan teknik reduksi data, penyajian data dan penarikan simpulan. Hasil penelitian menunjukkan adanya kesalahan berbahasa dalam bidang morfologi yakni 7 kesalahan diksi, 6 kesalahan penulisan imbuhan, 3 kesalahan singkatan kata, 2 kesalahan istilah asing, dan 2 kesalahan penulisan huruf kapital. Kesalahan yang sering ditemui adalah penulisan diksi dan imbuhan. Kesalahan penyingkatan kata terjadi karena pejabat ingin memberi informasi sesingkat mungkin kepada masyarakat. Tetapi kesalahan diksi dan imbuhan adalah murni kurangnya pengetahuan akan berbahasa Indonesia yang baik dan benar. Hal tersebut bisa menimbulkan makna yang berbeda dalam penulisan takrir. Solusi dan sarannya adalah pejabat memiliki tim humas khusus yang berpengalaman dalam bidang bahasa untuk menangani kesalahan penulisan sehingga dapat diminimalkan.
\end{abstract}

Kata kunci: media sosial, takrir, morfologi

\section{A. PENDAHULUAN}

Pejabat pemerintahan dituntut untuk tampil di ruang-ruang publik agar dekat dengan rakyatnya. Dalam hal ini mereka bisa juga disebut sebagai pejabat publik, yaitu pejabat pemerintahan yang memiliki andil tindakan di ruang publik. Media sosial adalah salah satu fasilitas publik. Media sosial sekarang banyak digunakan rakyat Indonesia untuk berkomunikasi dan berinteraksi satu sama lain. Sebagai media yang paling banyak digunakan oleh rakyat saat ini, media sosial dimanfaatkan oleh pejabat-pejabat pemerintahan di Indonesia untuk berkomunikasi dengan rakyatnya.

Fasilitas publik berupa media sosial telah menjadi fonemena tersendiri untuk berkomunikasi. Salah satu yang memanfaatkannya adalah pemerintahan. Pemerintahan yang memanfaatkan media sosial dapat berupa sektor lembaga, humas pemerintah, maupun individu kepala pemerintahan. Sektor lembaga biasanya dikelola oleh tim humas untuk melayani ruang komunikasi lembaga pemerintah dengan publik di media sosial. Humas pemerintah biasanya dikelola oleh tim humas sebagai juru bicara untuk melayani hubungan 
pemerintahan daerah tertentu dengan rakyat di media sosial. Sedangkan individu kepala pemerintahan biasanya dikelola oleh individu itu sendiri maupun tim humas sebagai pengelola media sosial untuk memanfaatkan media sosial untuk berkomunikasi dengan rakyatnya.

Kepala pemerintahan yang menggunakan media sosial secara aktif menarik minat peneliti. Sebagai pejabat publik kepala pemerintahan dituntut untuk berkomunikasi dengan rakyatnya secara baik. Walaupun ada beberapa akun media sosial kepala pemerintahan yang dipegang oleh tim humas, masih ada beberapa dari mereka yang menangani komunikasi dengan rakyat secara mandiri. Komunikasi yang dilakukan oleh pejabat pemerintahan di media sosial bermacam-macam, ada yang bersifat formal juga ada yang lebih bersifat anak muda. Perbedaan tersebut biasanya dipengaruhi oleh pengelola media sosial itu sendiri.

Perbedaan penggunaan bahasa tersebut menarik perhatian penulis. Bagaimana pejabat pemerintahan menggunakan bahasa Indonesia yang baik dan benar dalam berkomunikasi di media sosial. Media sosial adalah tempat dimana kebebasan dan kedinamisan komunikasi/interaksi. Artinya simbol keformalan ataupun keakraban bisa muncul di sini. Tidak ada peraturan khusus di sini. Namun bahasa yang digunakan memiliki panduan penggunaan, untuk itulah penulis akan meneliti penggunaan babasa Indonesia di dalam postingan akun media sosial pejabat pemerintahan.

Penulis secara khususkan mengkaji akun-akun gubernur yang aktif menggunakan media sosial. Media sosial yang populer digunakan adalah instagram dan twitter. Penggunaan media sosial tersebut banyak digunakan di Indonesia dan juga pejabat pemerintahan. Tujuan penelitian ini yaitu untuk mengetahui kesalahan berbahasa dalam tataran morfologi pada media sosial gubernur di Indonesia.

\section{B. KAJIAN PUSTAKA}

Kesalahan kalimat berbahasa terjadi dengan alasan karena kalimat membicarakan katakata, juga penggabungan dari kata-kata tersebut dan hal ini sangat luas cakupannya dan perlu dibahas secara khusus Sainik dan Zamzani (2015:53). Selain itu, terjadinya kesalahan berbahasa, yaitu penyimpangan atau kelanggaran bahasa yang tidak sesuai dengan kaidah bahasa Indonesia baku, baik kesalahan pemilihan kata, struktur, maupun gramatikal. Kesalahan-kesalahan ini wajar dialami oleh setiap penutur yang berdwibahasa (Afnita, Kurnia, dan Assadiyah, 2018).

Kesalahan berbahasa Indonesia di dalam media sosial menggunakan berbagai bidang linguistik sesuai media yang digunakan. Penelitian ini akan mengkaji akun media sosial 
gubernur khususnya di platform twitter dan instagram. Di dalam kedua media sosial tersebut dapat menggunakan media video, gambar, dan teks. Teks takrir lebih dominan digunakan dalam media komunikasi gubernur di media sosial tersebut walaupun biasanya dipadankan dengan gambar maupun video pendukung.

Berdasarkan jenis-jenis kesalahan berbahasa, Pateda (dalam Uswati dan Nuryanto, 2018) menjelaskan bahwa analisis kesalahan berbahasa dibagi ke dalam daerah-daerah kesalahannya. Menurut pateda daerah kesalahan berbahasa dibagi menjadi empat, antara lain daerah kesalahan fonologi, morfologi, sintaksis, dan daerah kesalahan semantis. Meskipun daerah kesalahan tersebut sudah diklasifikasikan, tetapi antara daerah kesalahan bahasa satu dengan yang lain saling berhubungan.

Sumber kesalahan berbahasa tataran morfologi bahasa Indonesia antara lain; (1) salah penentuan bentuk asal, (2) fonem yang luluh tidak diluluhkan, (3) fonem yang tidak luluh diluluhkan, (4) penyingkatan morfem men-, meny-, meng-, dan menge- menjadi $n$, ny, ng, dan nge-, (5) perubahan morfem ber-, per-, dan ter-, menjadi be-, pe-, dan te-. (6) penulisan morfem yang salah, (7) pengulangan yang salah, (8) penulisan kata majemuk serangkai, (9) pemajemukan berafiksasi, (10) pemajemukan dengan afiks dan sufiks, dan (10) perulangan kata majemuk.

Artikel jurnal yang membahas kesalahan bidang morfologi ini salah satunya yaitu jurnal yang disusun oleh Bayu Dwi Nurwicaksono dan Diah Amelia. Jurnal yang berjudul Analisis Kesalahan Berbahasa Indonesia pada Teks Ilmiah Mahasiswa menganalisis kesalahan-kesalahan berbahasa pada penulisan kata depan (preposisi), kesalahan karena pleonasme, kesalahan penulisan imbuhan, penulisan diksi, dsb. pada teks ilmiah mahasiswa.

\section{METODE PENELITIAN}

Penelitian ini adalah penelitian kualitatif. Penelitian ini membahas tentang kesalahan berbahasa dalam bidang morfologi, penelitian ini meneliti kesalahan penulisan takrir dalam akun pejabat gubernur-gubernur di Indonesia. Data pada penelitian ini kutipan postingan dari akun instagram dan twitter milik gubernur di Indonesia. Pengumpulan data penelitian menggunakan teknik simak dan catat. Metode simak yaitu merupakan metode penyediaan data yang dilakukan dengan cara menyimak penggunaan bahasa. Dalam teknik simak catat, peneliti sebagai instrumen kunci melakukan penyimakan secara cermat, terarah, dan teliti terhadap sumber data yang sesuai dengan tujuan penelitian. Setelah dilakukan penyimakan, diteruskan pencatatan terhadap data yang relevan dan yang sesuai dengan tujuan penelitian 
sehingga dapat ditentukan klasifikasi data. Teknik analisis data menggunakan teknik reduksi data, penyajian data dan penarikan simpulan.

\section{HASIL PENELITIAN DAN PEMBAHASAN}

Berdasarkan hasil penelitian mengenai kesalahan berbahasa pada takrir media sosial gubernur di Indonesia disajikan sebagai berikut:

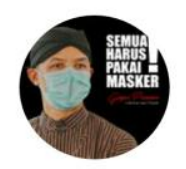

Ganjar Pranowo \& @ganjarpran... . 08 Jun

Pasar Karanganyu Semarang tiga hari ke depan

DITUTUP setelah kmrn tiga orang dinyatakan positif COVID-19. Pasar akan disterilisasi kemudian ditata ulang. Ayo teman2 pedagang maupun pengunjung pasar, taati protokol kesehatan, jaga jarak, pakai masker dan sering cuci tangan.

Gambar 1. Takrir Gubernur Jawa Tengah, Ganjar Pranowo

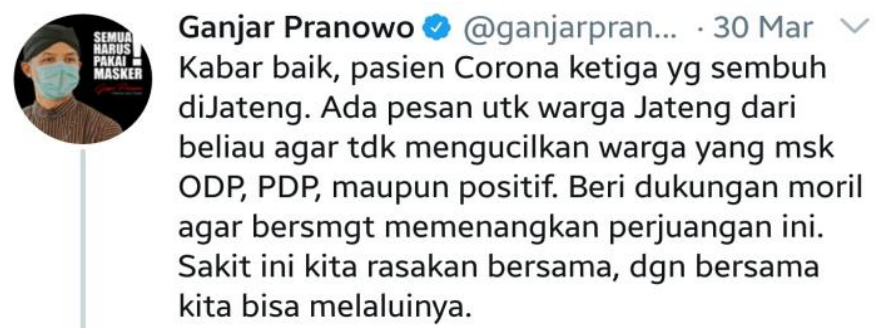

Gambar 2. Takrir Gubernur Jawa Tengah, Ganjar Pranowo

Beberapa kesalahan berbahasa yang ditemui dari beberapa gubernur saja yang aktif bermedia sosial di twitter maupun Instagram. Berikut ini adalah kesalahan.

1. Takrir Gubernur Jawa Tengah Ganjar Pranowo

Imbuhan di- pada kata diJateng sebaiknya dipisah menjadi di Jateng. Diksi pada kata moril tidak baku, penulisan yang benar adalah morel. Penyingkatan kata bersmngt yang memiliki arti bersemangat tidak sesuai dengan kaidah efisiensi bahasa.

2. Takrir Gubernur Jawa Tengah Ganjar Pranowo

Kata imbuhan ke- pada kalimat ke depan harusnya digabungkan karena memiliki makna bentuk kegiatan dan bukan menunjukan keterangan tempat. Penyingkatan kata kmrn yang memiliki arti kemarin tidak sesuai dengan kaidah efisiensi bahasa. Pada kata teman2 harusnya ditulis dengan teman-teman. Kata kerja pakai harusnya memiliki imbuhan meN- menjadi memakai. 


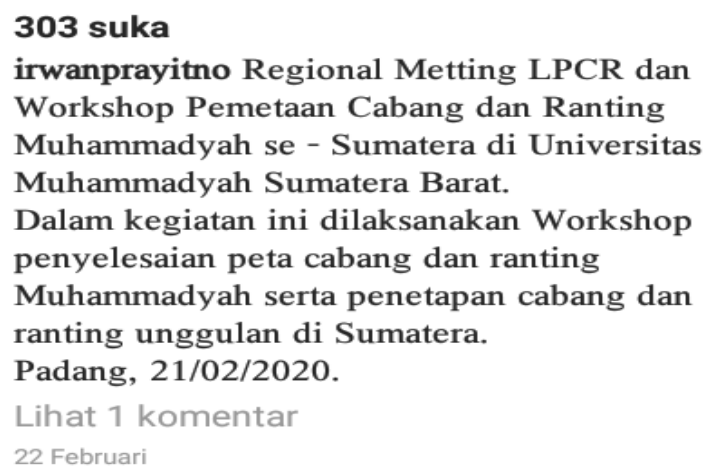

Gambar 3. Takrir Gubernur Sumatra Barat Irwan Prayitno

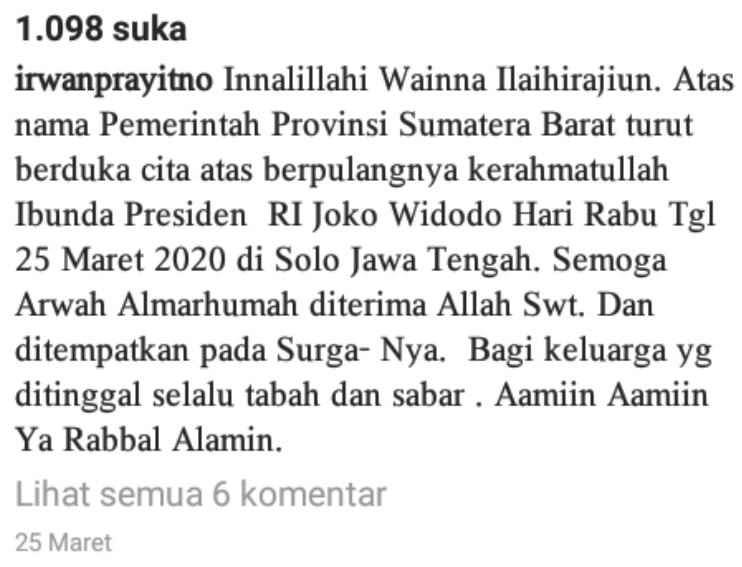

Gambar 4. Takrir Gubernur Sumatra Barat Irwan Prayitno

3. Takrir Gubernur Sumatra Barat Irwan Prayitno

Penggunaan istilah asing Regional Metting harusnya bisa diganti dengan padanan Pertemuan regional/wilayah. Kesalahan ketik penulisan Muhammadyah, seharusnya Muhammadiyah. Kesalahan tanda baca pada kata se - Sumatra harusnya digabung sehingga menjadi se-Sumatra. Kesalahan penggunaan istilah asing dan huruf kapital untuk kata Workshop, seharusnya pelatihan.

4. Takrir Gubernur Sumatra Barat Irwan Prayitno

Pada kata kerahmatullah seharusnya kata ke dipisah karena itu fungsinya menjadi kata depan bukan sebagai imbuhan, sehingga menjadi ke Rahmatullah. Penulisan kapital dalam kata Dan seharusnya tidak perlu, menjadi dan.

5. Takrir Gubernur Sumatra Utara Edy Rahmayadi 


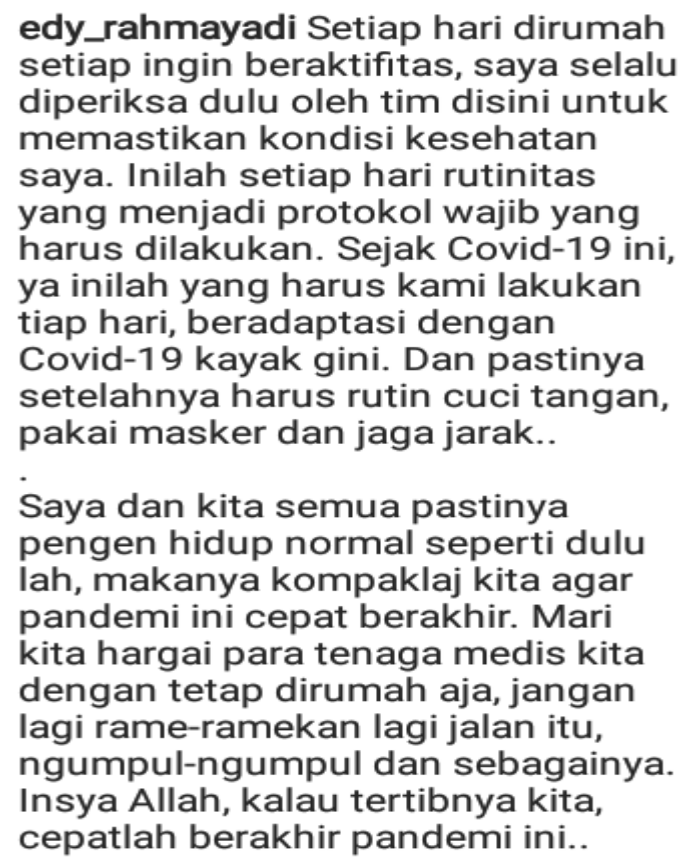

Gambar 5. Takrir Gubernur Sumatra Utara , Edy Rahmayadi

Pada kata dirumah seharusnya itu dipisah karena kata di- bukan imbuhan melainkan kata depan yang menunjukkan tempat sehingga menjadi di rumah. Kata aktifitas menjadi aktivitas. Karena huruf $f$ apabila di tengah kata akan berubah penulisannya menjadi huruf $v$.

6. Takrir Gubernur Kepulauan Bangka Belitung

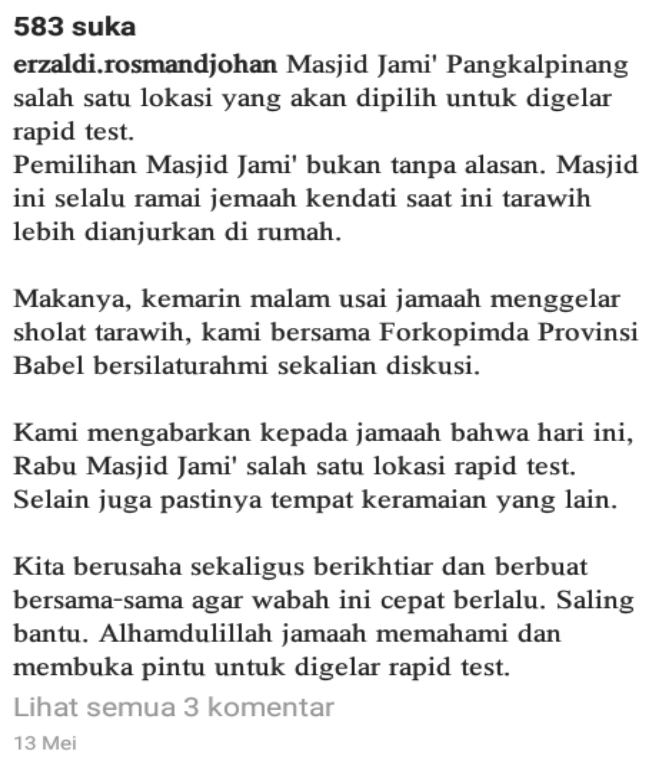

Gambar 6. Takrir Gubernur Kepulauan Bangka Belitung

Kata Pangkalpinang seharusnya dipisah menjadi Pangkal Pinang. Berdasarkan KBBI, kata jamaah seharusnya diganti menjadi jemaah. 
7. Takrir Gubernur Kepulauan Bangka Belitung

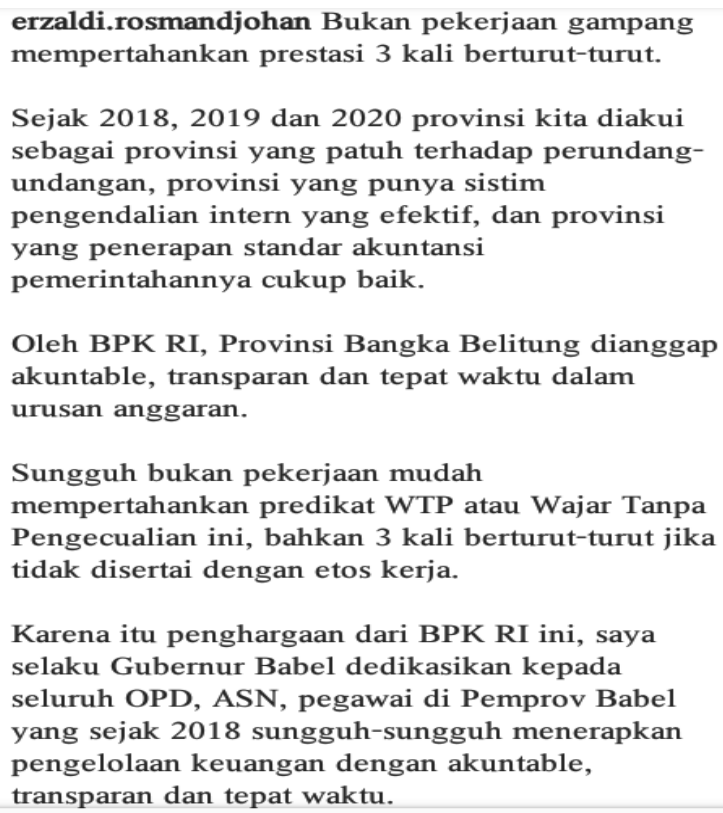

Gambar 7. Takrir Gubernur Kepulauan Bangka Belitung

Kata sistim belum baku, dalam KBBI kata sistim memiliki bentuk baku sistem. Kata akuntable belum baku, dalam KBBI kata akuntable memiliki bentuk baku akuntabilitas

\section{E. SIMPULAN}

Berdasarkan analisis data dari penelitian ini dapat disimpulkan masih banyaknya kesalahan berbahasa dalam bidang morfologi. Terdapat 7 kesalahan diksi, 6 kesalahan penulisan imbuhan, 3 kesalahan singkatan kata, 2 kesalahan istilah asing, dan 2 kesalahan penulisan huruf kapital. Kesalahan yang sering ditemui adalah penulisan diksi dan imbuhan. Kesalahan penyingkatan kata terjadi karena pejabat ingin memberi informasi sesingkat mungkin kepada masyarakat. Tetapi kesalahan diksi dan imbuhan adalah murni kurangnya pengetahuan akan berbahasa Indonesia yang baik dan enar. Hal tersebut bisa menimbulkan makna yang berbeda dalam penulisan takrir. Solusi dan sarannya adalah pejabat memiliki tim humas khusus yang berpengalaman dalam bidang bahasa untuk menangani kesalahan penulisan sehingga dapat diminimalkan.

\section{F. DAFTAR PUSTAKA}

Sainik, Paramvir, dan Zamzani. Analisis Kesalahan Kalimat Pada Karangan Berbahasa Indonesia Mahasiswa Di Jawaharlal Nehru University New Delhi, India. Lingtera. Vol 2 No 12015 https://journal.uny.ac.id/index.php/ljtp/article/view/5407

Afnita, Eriska Kurnia, dan Herfina Assadiyah. 2018. Analisis Kesalahan Berbahasa Bidang Sintaksis dalam Teks Biografi Siswa Kelas X SMA Negeri 7 Padang. Deiksis: Jurnal Pendidikan Bahasa dan Sastra Indonesia. Deiksis: Jurnla Pendidikan Bahasa dan Sastra Indonesia. Vol 5 No 22018 
Lingua Rima: Jurnal Pendidikan Bahasa dan Sastra Indonesia

Vol. 9 No. 2 Juli 2020

http://jurnal.unswagati.ac.id/index.php/Deiksis/article/view/1197

Uswati, Tati Sri, dan Tato Nuryanto.2018. Kesalahan Sintaksis Pada Skripsi Mahasiswa IAIN Syekh Nurjati Cirebon. Indonesian Language Education and Literature. Vol 4 No 1 2018. http://www.syekhnurjati.ac.id/jurnal/index.php/jeill/article/view/1880 